\title{
Analisis Fleksibilitas Strategis Perkembangan Usaha Kilang Batu Bata Pasca Pandemi COVID-19 (Studi Kasus: Kota Banda Aceh)
}

\author{
Ijal Fahmi ${ }^{1 *}$, Ilyas ${ }^{2}$ \\ 1*,2 Program Studi Manajemen, Fakultas Ekonomi, Universitas Serambi Mekkah, \\ Kota Banda Aceh, Provinsi Aceh, Indonesia.
}

\begin{abstract}
Abstrak. Tujuan kbusus dari penelitian ini adalah; 1) Untuk mengetabui perkembangan produksi, modal kerja, tenaga kerja, volume penjualan, tingkat upah, harga jual, biaya bahan dan keuntungan pelaku usaha industri batu bata, 2) Untuk mengetahui kelayakan usaha batu bata di Kota Banda Aceh, dan 3) Untuk menganalisis fleksibilitas strategis perkembangan usaha kilang batu bata pasca pandemi COVID-19. Analisis deskriptif dan kuantitatif digunakan untuk menganalisis data, dengan pengamatan langsung terhadap suatu obyek penelitian guna mengetahui keadaan lokasi usaha dan karakteristik. Usaha Batu Bata di Kota Banda Aceh, Dalam rangka menentukan layak atau tidak usaha tersebut dijalankan dengan menggunakan perbitungan analisis BCR. Berdasarkan hasil penelitan dan pembahasan, dapat disimpulkan bahwa perkembangan Usaba kilang Batu Bata diketahui Hasil analisis data mengenai Jumlah Produksi, Tenaga Kerja, Modal Kerja, Volume Penjualan, Tingkat Upah, Harga Jual, Biaya Bahan Baku dan Keuntungan Usaha Kilang Batu Bata mengalami peningkatan setiap tahun. Berbeda pada tahun 2020-2021 terjadi penurunan yang diakibatkean oleb menurunya permintaan dan tingginya bahan baku pengolahan batu bata. Hasil perbitungan kelayakan usaba ditinjau dari segi Modal dan Penerimaan dengan menggunakan rumus BCR yang menunjukkan bahwa variabel modal dan penerimaan berpengaruh positif terhadap kelayakan Usaha Kilang Batu Bata 2017 s/d tabun 2019 ataupun dalam arti kata lain bahwa Usaha Kilang Batu Bata tidak rugi. Terbalik pada tabun 2020-2021 dimana usaba batu bata menurunya permintaan tetapi stok menjadi banyak dan tidak ditemukan kerugian yang berdampak. Akan tetapi, pendapatan usaha batu bata menjadi menurun. Usaha kilang batu bata dilihat dari aspek pemasaran mengalami perkembangan yang positif pada tabun 2017-2019, hal ini dapat dilihat dari jumblah permintaan yang selalu meningkat setiap tahunnya. Berbeda pada tabun 2020-2021 dimana perkembangan dari aspek pemasaran menjadi rendah, dikarena adanya pandemic dan berkurangnya pembangunan di Kota Banda Aceh.
\end{abstract}

Kata kunci: Analisis; Fleksibilitas; Strategis; Perkembangan; Usaba Kilang Batu Bata; Pasca Pandemi; COVID-19; Kota Banda Aceh.

\begin{abstract}
The specific objectives of this research are; 1) To find out the development of production, working capital, labor, sales volume, wage level, selling price, material costs, and profits of brick industry business actors, 2) To determine the feasibility of brick business in Banda Aceb City, and 3) To analyze strategic flexibility in the development of the brick refinery business after the COVID-19 pandemic. Descriptive and quantitative analysis was used to analyze the data, with direct observation of a research object in order to determine the condition of the business location and the characteristics of the brick business in Banda Aceh City. In order to determine whether or not the business was feasible, the business was carried out using BCR analysis calculations. Based on the results of research and discussion, it can be concluded that the development of the brick refinery business is known. The results of data analysis regarding the amount of production, labor, working capital, sales volume, wages, selling prices, raw material costs, and business profits of the brick refinery have increased every year. In contrast, in 2020-2021 there will be a decline caused by declining demand and high raw materials for brick processing. The results of the calculation of business feasibility in terms of Capital and Revenue using the BCR formula show that the capital and revenue variables have a positive effect on the feasibility of the 2017 to 2019 Brick. Refinery Business or in other words that the Brick Refinery Business does not lose. It was reversed in 2020-2021 where the brick business decreased in demand but the stock became large and no significant losses were found. However, the bricks business revenue bas decreased. The brick refinery business seen from the marketing aspect experienced positive developments in 2017-2019, this can be seen from the number of requests that always increase every year. It is different in 2020-2021 where the development from the marketing aspect is low, due to the pandemic and reduced development in Banda Aceh City.
\end{abstract}

Keywords: Analysis; Flexibility; Strategic; Development; Brick Refinery Business; Post Pandemic; COVID-19; Banda Aceh City.

*Corresponding Author. Email: ijalfahmi@serambimekkah.ac.id ${ }^{1 *}$.

DOI: https://doi.org/10.35870/emt.v5i2.474

Received: 07 September 2021, Revision: 24 October 2021, Accepted: 1 November 2021.

Print ISSN: 2579-7972; Online ISSN: 2549-6204.

Copyright@2021. Published by Lembaga Otonom Lembaga Informasi dan Riset Indonesia (KITA INFO dan RISET).

163 | Jurnal Ekonomi dan Manajemen Teknologi Vol. 5 | No. 2 | 2021 


\section{Pendahuluan}

Dalam pembangunan ekonomi di Indonesia Usaha Mikro Kecil dan Menegah (UMKM) selalu digambarkan sebagai sektor yang mempunyai peranan yang penting (Kristiyanti, 2012), karena sebagian besar jumlah penduduknya berpendidikan rendah dan hidup dalam kegiatan usaha kecil baik sektor tradisional maupun modern. Menurut UU No. 20 Tahun 2008 tentang Usaha Mikro, Kecil, dan Menengah dalam pasal 3 disebutkan bahwa Usaha Mikro, Kecil, dan Menengah bertujuan menumbuhkan dan mengembangkan usahanya dalam rangka membangun perekonomian nasional berdasarkan demokrasi ekonomi yang berkeadilan (Indriasari, Suryanti, \& Afriana, 2017). Pengembangan Usaha Mikro Kecil dan Menengah (UMKM) perlu mendapatkan perhatian yang besar baik dari pemerintah maupun masyarakat agar dapat berkembang lebih kompetitif bersama pelaku ekonomi lainnya. Kebijakan pemerintah ke depan perlu meningkatkan perannya dalam memberdayakan Usaha Mikro Kecil dan Menengah (UMKM) disamping mengembangkan kemitraan. usaha yang saling menguntungkan antara pengusaha besar dengan pengusaha kecil, dan meningkatkan kualitas Sumber Daya Manusianya (Utama \& Darwanto, 2013).

Namun dalam perkembangannya, industri kecil masih belum menjalankan fungsi dan peranannya secara maksimal karena menghadapi berbagai kendala seperti masalah keterbatasan modal, Teknik produksi, bahan baku, pemasaran, manajemen dan teknologi (Darsih, Iyan, \& Pailis, 2017). Ditambah lagi, Pandemi COVID-19 menbawa dampak ekonomi yang mematikan bagi pelaku UMKM (Pakpahan, 2020). Langkah-langkah penguncian (lockdown) telah menghentikan aktivitas ekonomi secara tiba-tiba, dengan penurunan permintaan dan mengganggu rantai pasokan di seluruh dunia (Thaha, 2020). Pelaku UMKM juga dituntut untuk dapat mengkomunikasikan produk secara intensif dengan melakukan pemasaran produk menggunakan digital marketing dan memanfaatkan media sosial untuk dapat menjangkau konsumennya secara langsung dan dapat menekan biaya promosi (Laura Hardilawati, 2020).

Meski prospek industri batu bata cukup baik, namun pada kenyataannya masih banyak pengrajin batu bata yang harus berhenti berproduksi karena belum memperhitungkan keuntungan dan biaya secara jelas dari awal menjalankan usaha. Hal ini terjadi pada pengrajin batu bata masih berproduksi pada saat ada permintaan saja dan tanpa menggunakan strategi pemasaran yang baik. Pandemi covid-19 ini menyebabkan adanya pergeseran dan perubahan pola pembelian konsumen (Djatmiko \& Pudyastiwi, 2020). Perlu adanya perbaikan kualitas produk dan penyesuaian pelayanan untuk dapat menarik konsumen (Kamila, 2020). Strategi manajemen pasca pandemi COVID-19 implementasi strategi pemasaran sebagai upaya untuk menciptakan eksistensi bisnis usaha yang lebih efisien dan efektif bagi pelaku UMKM sehingga memiliki manajemen pengetahuan yang baik dan absorptive capacity untuk meningkat kinerja bisnisnya (Narto, 2020).

Penelitian ini dilakukan untuk menjawab apa yang dapat dilakukan pelaku UMKM untuk dapat mempertahankan bisnis mereka pasca Pandemik COVID-19, serta mendeskripsikan dan menjabarkan apa saja strategi bertahan yang harus dilakukan oleh pelaku UMKM sehingga mereka mampu terus bertahan dan menjadi lebih responsif terhadap perubahan iklim bisnis terutama pasca COVID-19. Berdasarkan latar belakang, maka tujuan khusus dari penelitian ini adalah:

1) Untuk mengetahui perkembangan produksi, modal kerja, tenaga kerja, volume penjualan, tingkat upah, harga jual, biaya bahan dan keuntungan pelaku usaha industri batu bata,

2) Untuk mengetahui kelayakan usaha batu bata di Kota Banda Aceh, dan

3) Untuk menganalisis fleksibilitas strategis perkembangan usaha kilang batu bata pasca pandemi COVID-19.

Hingga saat ini kajian mengenai keterkaitan antara perkembangan usaha industri batu bata dengan perkembangan usaha pasca pandemi COVID-19 belum banyak dilakukan. Padahal kajian empiris mengenai pentingnya 
menganalisis

perkembangan

fleksibilitas

UMKM dalam upaya

peningkatan usaha UMKM sangat penting.

Penelitian ini dianggap penting selain dapat memperkaya bukti empiris mengenai keterkaitan antara variabel-variabel tersebut, hasil penelitian juga dapat memberikan rekomendasi kebijakan bagi usaha batu bata di Kota Banda Aceh terkait dalam rangka penerapan strategis pada perkembangan usaha UMKM.

\section{Literature Review}

\section{Usaha Mikro Kecil Dan Menengah}

Usaha Mikro Kecil dan Menengah (UMKM) menurut Undang-Undang Republik Indonesia Nomor 20 tahun 2008 tentang usaha mikro, kecil dan menengah (Indriasari, Suryanti, \& Afriana, 2017). Usaha mikro adalah usaha produktif milik orang, perorangan dan atau badan usaha perorangan yang memenuhi kriteria usaha mikro sebagaimana diatur dalam Undang- Undang ini.Usaha kecil adalah usaha ekonomi produktif yang berdirisendiri, yang dilakukan oleh orang, perorangan atau badan usaha yang bukan merupakan anak perusahaan atau bukan cabang perusahaan yang dimiliki, dikuasai atau menjadi bagian baik langsung maupun tidak langsung dari usaha menengah atau usaha besar yang memenuhi kriteria usaha kecil sebagaimana dimaksud dalam UndangUndang ini (Suci, 2017).

Industri kecil dan menengah (UKM) di Indonesia memiliki peranan yang cukup besar, antara lain penyerapan tenaga kerja yang tinggi, penghasil devisa dan meningkatkan pendapatan dan kesejahteraan masyarakat. Indonesia mengalami masalah kependudukan seperti negara berkembang lainnya, masalah tersebut berupa tingginya laju pertumbuhan penduduk yang tidak sebanding dengan laju pertumbuhan tenaga kerja (Hardiyanto, 2019). Industri kecil dan menengah (UKM) menyerap tenaga kerja dalam jumlah besar seperti halnya industri besar. Industri kecil dan menengah tidak hanya menyerap tenaga kerja dalam jumlah besar, bahkan tenaga kerja dengan tingkat pendidikan yang rendah. Kemampuan industri kecil dan menengah menyerap tenaga kerja yang pendidikannya rendah sangat sesuai dengan angkatan kerja Indonesia yang rata-rata berpendidikan rendah. Penyerapan tenaga kerja yang cukup tinggi akan meningkatkan pendapatan dan kesejahteraan para pekerja. Peningkatan pendapatan para pekerja pada akhirnya akan meningkatkan pendapatan daerah dan akan mengurangi kecenderungan penduduk untuk bermigrasi ke daerah lain atau ke kota. permasalahan yang dihadapi usaha mikro kecil dan menengah Permasalahan yang dianggap mendasar bagi UMKM adalah adanya kecenderungan pemerintah dalam menjalankan program untuk pengembangan UMKM seringkali merupakan Tindakan koreksi terhadap kebijakan lain yang berdampak merugikan usaha kecil". Selain permasalahan tersebut, secara umum UMKM sendiri mempunyai dua permasalahan utama, yaitu permasalahan finansial dan masalah non finansial (Budiarto dkk, 2018).

\section{Industri Batu Bata}

Industri batu bata merupakan industri yang memanfaatkan tanah sebagai bahan baku utama (As, Novareza, \& Santoso, 2017). Dalam penelitian ini yang dimaksud dengan industri batu bata yaitu suatu proses produksi yang di dalamnya terdapat perubahan bentuk dari benda yang berupa tanah liat menjadi bentuk lain (batu bata), sehingga lebih berdaya guna. Industri rumah tangga batu bata sebagai industri rumah tangga mempunyai ciri-ciri yaitu:

1) Modal kecil,

2) Usaha dimiliki pribadi,

3) Menggunakan teknologi dan peralatan yang sederhana, jumlah tenaga kerja relatif sedikit.

4) Sedangkan sifat industri rumah tangga batu bata adalah bersifat tidak berbadan hukum (Inayah, 2018).

\section{Produksi}

Produksi dapat diartikan sebagai sebuah kegiatan menghasilkan barang atau jasa, tetapi juga kegiatan yang sifatnya menambah nilai atau kegunaan barang yang sudah ada menjadi lebih tinggi nilainya. Tujuan dari produksi itu sendiri adalah untuk menghasilkan/menciptakan suatu barang, menambah serta meningkatkan nilai guna barang yang sudah ada, memperoleh tembahan penghasilan serta untuk memenuhi semua kebutuhan manusia (Wijayanti \& 
Mulyati, 2018). Produksi adalah mengubah barang agar mempunyai kegunaan untuk memenuhi kebutuhan manusia (Vicky, 2019). Jadi produksi merupakan segala kegiatan untuk menciptakan atau menambahguna atas suatu benda yang ditunjukkan untuk memuaskan orang lain melalui pertukaran. Produksi menghasilkan barang dan jasa sedangkan bagaimana tahapan tahapan produksi dinamai proses produksi karena proses produksi mempunyai landasan teknis yang dalam teori ekonomi disebut fungsi produksi. Produksi merupakan hasil akhir dari proses atau aktivitas ekonomi dengan memanfaatkan beberapa masukan atau input. Produksi atau memproduksi menambah kegunaan (nilai guna) suatu barang. Kegunaan suatau barang akan bertambah bila memberikan manfaat baru atau lebih dari bentuk semula Berdasarkan pendapat di atas dapat disimpulkan bahwa Produksi adalah mengubah barang agar mempunyai kegunaan untuk memenuhi kebutuhan manusia (Ramadan \& Rosyidi, 2017).

\section{Aspek Pemasaran}

Analisis pasar untuk hasil tempat usaha sangat penting untuk meyakinkan bahwa terdapat suatu permintaan yang efektif pada suatu harga yang menguntungkan.Analisis aspek pasar dilakukan dengan mengamati kecenderungan permintaan untuk melihat potensi pasar yang masih terbuka luas. Selain itu, aspek ini juga menganalisis rencana pemasaran output yang dihasilkan oleh proyek (Yuniarti, 2018).

Pemasaran merupakan titik tolak kerangka pemikiran dalam suatu studi kelayakan, karena aspek inilah yang akan menentukan apakah pengkajian aspek-aspek lainnya perlu diteruskan atau tidak (Agustin, 2017). Hal ini penting karena dalam suatu sistem perekonomian yang relatif bebas, usaha swasta diperkenankan bersaing di pasar. Konsekuensinya, barang dan jasa yang dihasilkan oleh perusahaan harus dapat memenuhi kebutuhan dan keinginan konsumen.Hal-hal yang menjadi permasalahan dalam aspek pasar adalah (1) permintaan, baik secara total maupun diperinci menurut daerah, jenis konsumen, perusahaan besar pemakai; (2) penawaran, baik yang berasal dari dalam negeri maupun yang berasal dari luar negeri; (3) harga, yang dilakukan dengan perbandingan produksi dalam negeri lainnya; (4) strategi pemasaran, mencakup pemasaran yang akan dipergunakan, "marketting mix"; (5) Perkiraan penjualan yang bisa dicapai perusahaan,pangsa pasar (market share) yang bisa dikuasai perusahaan.

\section{Konsep Strategic Flexibility Analysis (SFA)}

Konsep ini pertama kali diperkenalkan oleh Sanchez (1997). Strategic flexibility sebagai sebuah kondisi dimana seorang pemimpin mampu untuk menerapkan keputusan strategis dengan mengkombinasikan pola koordinasi organisasi dengan sumber daya manusia yang fleksibel pada masa yang memiliki tingkat ketidakpastian yang tinggi (Solikin, Fatchurahman, \& Supardi, 2017). SFA merupakan sebuah kapabilitas dalam merespon lingkungan yang dinamis dengan menerapkan perubahan berkelanjutan dan berbagai aksi sistemis. Lebih lanjut, beliau mengemukakan bahwa konsep SFA ini memiliki empat komponen antara lain meliputi fleksibilitas pembagian kerja, fleksibilitas pola kepemimpinan, fleksibilitas pola transaksi dan pendidikan, serta fleksibilitas individu dalam perusahaan untuk saling menolong antar pekerja (Fathonah, 2018; Asang, 2019).

\section{Metodologi Penelitian}

\section{Lokasi, Populasi dan Sampel Penelitian}

Lokasi dalam penelitian ini di gampong pada Kota Banda Aceh, direncanakan pada bulan Januari 2021, sedangkan pengumpulan data primer/sekunder dan pengolahan data sampai penulisan dilakukan pada bulan Mei 2021 dan laporan pada akhir tahun. Objek dalam penelitian ini adalah perkembangan usaha kilang batu bata di Kota Banda Aceh sebanyak 297 sedangkan jumlah usaha menengah dan besar adalah sebanyak 320 (DEPPERINDAG, 2020).

\section{Data dan Teknik Pengumpulan Data}

Data yang dikumpulkan berupa data primer dan data sekunder. Data primer diperoleh melalui pengamatan, dan dengan cara mewawancarai pihak-pihak yang berkepentingan dalam penelitian. Data sekunder diperlukan sebagai penunjang data primer yang telah didapatkan. Pengambilan data sekunder berkaitan dengan keadaan umum lokasi penelitian, potensi UKM 
khususnya UKM di Kota Banda Aceh. Analisis deskriptif digunakan untuk menganalisis data, dengan pengamatan langsung terhadap suatu obyek penelitian guna mengetahui keadaan lokasi usaha dan karakteristik Usaha Batu Bata di Kota Banda Aceh. Analisis kuantitatif yang digunakan untuk melakukan perhitungan sebagai berikut:

$$
g=\frac{S_{1}-S_{0}}{S_{0}} \times 100 \%
$$

Keterangan :

$\mathrm{g}=$ Growth Sales Rate (tingkat pertumbuhan penjualan)

$\mathrm{S} 1=$ Total Current Sales (total penjualan selama periode berjalan)

S0 = Total Sales For Last Period (total penjualan periode yang lalu)

Dalam rangka menentukan layak atau tidak usaha tersebut dijalankan dengan menggunakan perhitungan sebagai berikut.

$$
B C R=\frac{\text { Total Penerimaan }}{\text { Total Biaya }}
$$

Analisis BCR merupakan perbandingan antara pendapatan total dengan total cost atau biaya produksi secara keseluruhan, apabila nilai $\mathrm{B} / \mathrm{C}$ rasio lebih kecil dari $1(\mathrm{~B} / \mathrm{C}$ ratio $<1)$ maka proyek itu tidak ekonomis dan apabila lebih besar dari $1(\mathrm{~B} / \mathrm{C}$ ratio $>1)$ maka proyek itu ekonomis, serta apabila sama dengan satu $(\mathrm{B} / \mathrm{C}$ ratio $=1)$ maka proyek itu marginal (tidak rugi dan tidak untung).

\section{Hasil dan Pembahasan}

Kota Banda Aceh merupakan daerah pusat pemerintah Provinsi Aceh, tercatat 9.591 data UMKM yang tersebar dari 9 Kecamatan. Berdasarkan data UMKM yang tersebar di Kota Banda Aceh, usaha kilang batu bata hanya berada pada Kecamatan Ulee Kareng. Terdapat 29 Usaha Kilang Batu Bata dengan Sektor Kecil sebesar 23 dan Mikro sebesar 6 usaha kilang batu bata, terlihat pada grafik 1 dibawah ini:

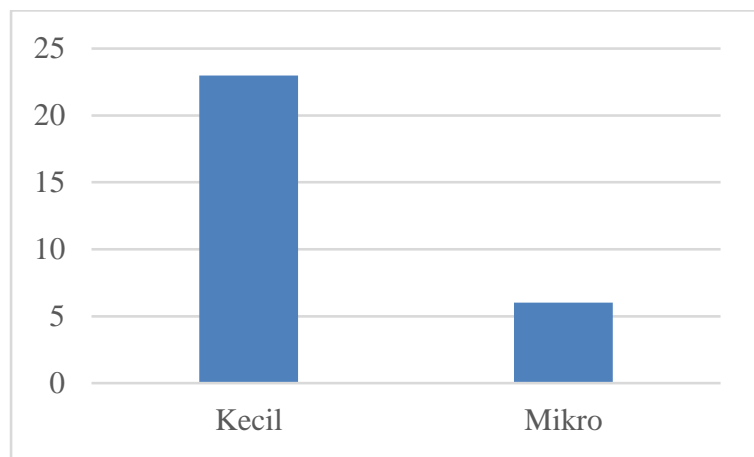

Grafik 1. Sektor UMKM Kilang Batu Bata

Usaha Kilang Batu Bata bertujuan untuk membantu kebutuhan akan bahan baku untuk membuat rumah. Keberhasilan suatu usaha dapat dilihat dari tercapainya tidaknya tujuan usaha-usaha. Dalam hal ini perusahaan mempunyai dua tujuan yang meliputi tujuan jangka pendek dan tujuan jangka panjang. Adapun tujuan-tujuan tersebut adalah sebagai berikut:

a) Tujuan Jangka Pendek

1. Membantu mencukupi kebutuhan masyarakat tentang.peralatan bahan bangunan

2. Mencapai terget yang telah ditentukan.

b) Tujuan Jangka Panjang

1. Mendapatkan keuntungan maksimal.

2. Meningkatkan kualitas, kuantitas serta harga yang lebih baik dan sesuai terutama untuk memperkuat posisi usaha batu bata dalam persaingan usaha sejenis.

3. Mencari kemungkinan perluasan usaha.

Analisis dilakukan melihat beberapa aspek penting dalam pengembangan usaha industri kilang batu bata berdasarkan aspek; lokasi, produksi, modal, biaya bahan baku, tenaga kerja, volume penjualan, tingkat upah, harga jual, dan keuntungan.

\section{Pembahasan Hasil Penelitian}

Pembahasan hasil penelitian merupakan penggambaran tentang hasil yang diperoleh dalam penelitian yang terdiri atas variabelvariabel independen dan variabel dependen. Dalam penelitian ini juga termasuk data atau keterangan yang terkait dengan laporan keuangan serta hasil wawancara yang telah dilakukan oleh penulis. Data yang diperoleh merupakan data Produksi, Modal Kerja, Tenaga 
Kerja, Volume Penjualan, Tingkat Upah, Harga Jual, Biaya Bahan Baku dan Keuntungan. Usaha kilang Batu Bata yang dipublikasikan dari tahun 2017 hingga tahun 2021. Sesuai dengan permasalahan dan perumusan masalah yang telah dikemukakan, serta kepentingan pengujian hipotesis, maka teknik analisis yang digunakan dalam penelitian ini meliputi analisis deskriptif dan analisis statistik. Analisis deskriptif merupakan analisis yang mengacu pada deskripsi kondisi perusahaan dan hasil wawancara yang dilakukan penulis. Analisis statistik merupakan analisis yang mengacu pada perhitungan data penelitian yang berupa angka-angka yang dianalisis dengan bantuan komputer melalui program statistical.

Perkembangan Produksi, Modal Kerja, Tenaga Kerja, Volume Penjualan, Tingkat Upah, Harga Jual, Biaya Bahan Baku dan Keuntungan. dalam penelitian ini digunakan untuk memberikan masukan kepada pengusaha kilang batu bata bahwa salah satu faktor penting yang harus diperhatikan dalam menjalankan usaha adalah pengelolaan Produksi, Modal Kerja, Tenaga Kerja, Volume Penjualan, Tingkat Upah, Harga Jual, Biaya Bahan Baku dan Keuntungan yang baik. Berdasarkan hasil penelitian dan wawancara yang penulis lakukan, Usaha Kilang Batu Bata setiap tahunnya melakukan penambahan modal kerja untuk kebutuhan produksi. Modal kerja tersebut digunakan untuk membiayai proses operasioanal perusahaan seperti pembelian tanah, pasir, kayu bakar dan pembelian traktor. Setiap tahunnya usaha kilang batu bata mengalami peningkatan produksi selama 5 tahun terakhir. Produk batu bata yang dihasilkan kemudian dipasarkan ke seluruh daerah ule kareng dan sekitarnya. Dengan bobot produksi yang cukup besar usaha kilang batu bata dapat memenuhi permintaan konsumen akan kebutuhan batu bata yang setiap tahunnya terus meningkat. Untuk itulah setiap tahunnya usaha kilang batu bata mengeluarkan kebijakan untuk menambah Produksi, Modal Kerja, Tenaga Kerja, Volume Penjualan, Tingkat Upah, Harga Jual, Biaya Bahan Baku, agar kontinuitas produksi terus terjaga dan mampu memenuhi permintaan para konsumen. Melihat tingginya permintaan konsumen terhadap batu bata, maka dapat dipastikan penjualan tiap tahunnya juga mengalami peningkatan. Jika penjualan mengalami peningkatan, maka profitabilitas perusahaan pastinya akan meningkat karena keuntungan atau laba bersih yang dihasilkan akan bertambah. usaha dianggap berkinerja bagus jika berhasil melampaui target produksi dan penjualan meupun laba bersih. Berikut adalah Produksi, Modal Kerja, Tenaga Kerja, Volume Penjualan, Tingkat Upah, Harga Jual, Biaya Bahan Baku, Usaha Kilang Batu Bata dari tahun 2017 hingga 2021.

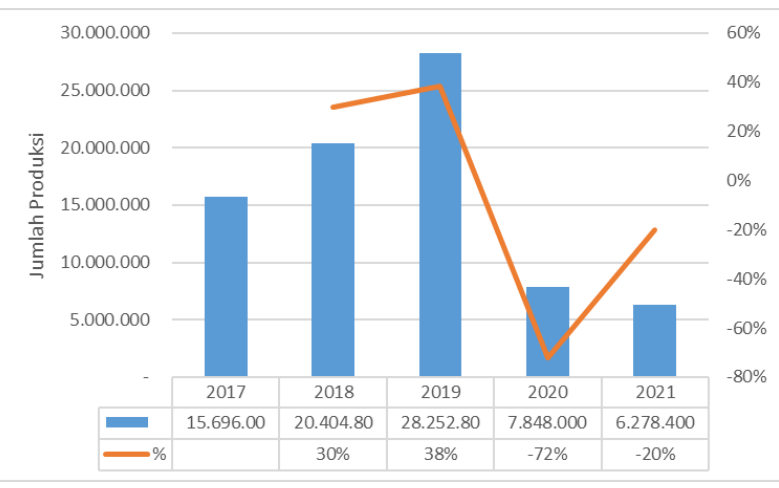

Grafik 2. Perkembangan Produksi Usaha Kilang Batu Bata

Jika diteliti lebih lanjut maka akan terlihat persentase kenaikan produksi setiap tahunya mengalami penurunan. untuk keseluruhan dalam 5 tahun terakhir, Usaha Kilang Batu Bata mengalami penurunan yang sangat pesat dilihat dari produksi. Hal ini jelas dipengaruhi oleh rendahnya permintaan batu bata khususnya di daerah Kota Banda Aceh dan daerah lain di Provinsi Aceh. selain itu usaha kilang batu bata juga menawarkan harga yang sangat tinggi.

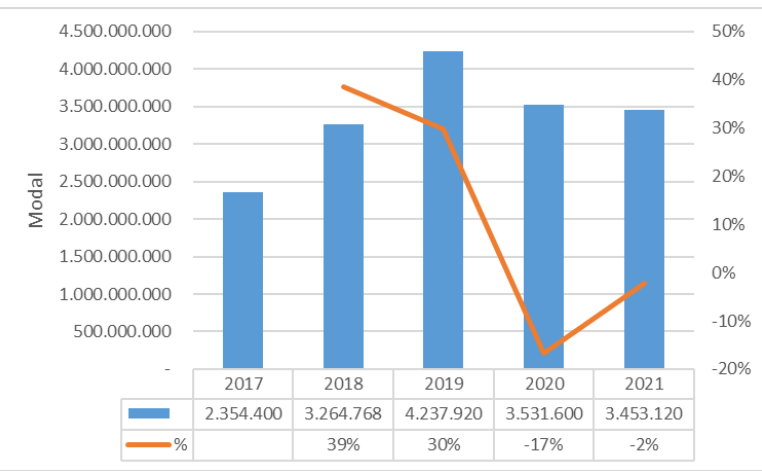

Grafik 3. Perkembangan modal Usaha Kilang Batu Bata

Jika diteliti lebih lanjut maka akan terlihat 
persentase modal operasional setiap tahunya mengalami peningkatan. Tetapi untuk keseluruhan, dalam 5 tahun terakhir, usaha kilang batu bata mengalami perkembangan yang sangat pesat dilihat dari produksi. Hal ini jelas dipengaruhi oleh tingginya permintaan batu bata khususnya di daerah Kota Banda Aceh dan sekitarnya. selain itu Usaha Kilang Batu Bata juga menawarkan harga yang sangat tinggi.

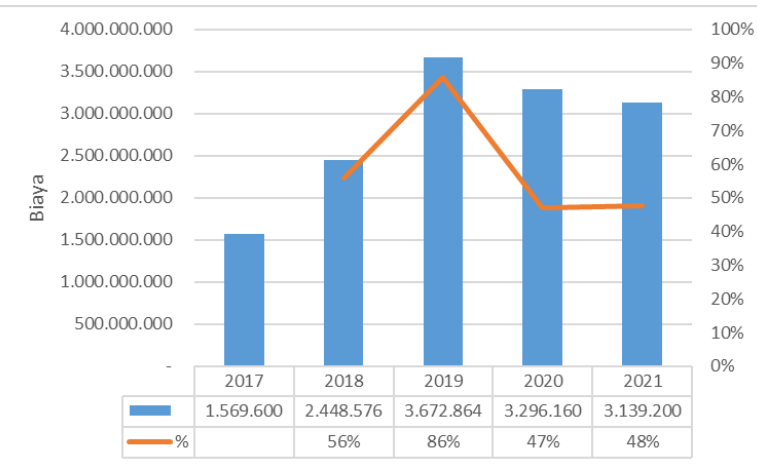

Grafik 4. Perkembangan Biaya Bahan Baku Usaha Kilang Batu Bata

Jika diteliti lebih lanjut maka akan terlihat persentase biaya bahan baku setiap tahunya mengalami peningkatan dalam 5 tahun terakhir, Usaha Kilang Batu Bata Mengalami perkembangan yang sangat pesat dilihat dari produksi. Hal ini jelas dipengaruhi oleh tingginya permintaan batu bata khususnya di daerah ulee kareng dan sekitarnya. selain itu Usaha Kilang Batu Bata juga menawarkan harga yang sangat murah. Berbeda pada tahun 2020 dan 2021 yang mengalami penurunan.

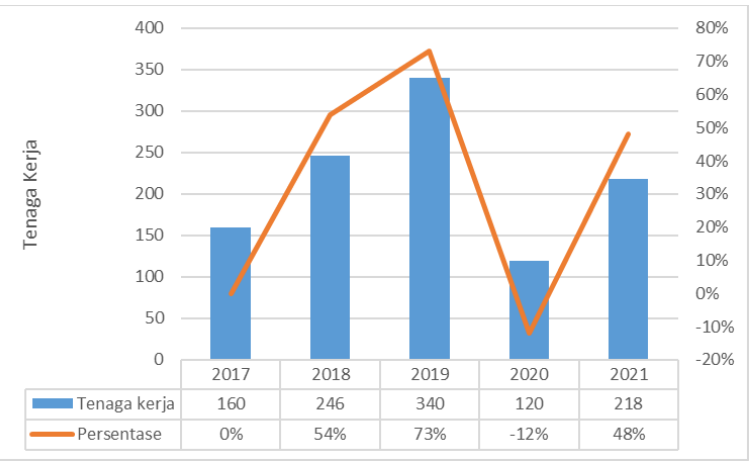

Grafik 5. Perkembangan Tenaga Kerja

Jika diteliti lebih lanjut maka akan terlihat persentase tenaga kerja usaha kilang batu bata setiap tahunya mengalami peningkatan. untuk keseluruhan dalam 5 tahun terakhir, usaha kilang batu bata mengalami perkembangan yang sangat pesat dilihat dari tenaga kerja. Hal ini jelas dipengaruhi oleh tingginya permintaan batu bata khususnya di daerah dan sekitarnya. Sedangkan pada tahun 2020-2021 dampak pandemic berdampak pada pengurangn tenaga kerja, walaupun pada tahun 2021 mengalami peningkatan tapi masih tidak diketahui kesejahteraan juga meningkat. Untuk lebih jelas dan memudahkan dalam mengetahui perkembangan volume penjualan Usaha kilang batu bata dari tabel di atas maka dibuatlah perkembangan volume penjualan. Berikut grafik perkembangan volume penjualan Usaha Kilang Batu Bata dari tahun 2017 sampai dengantahun 2021.

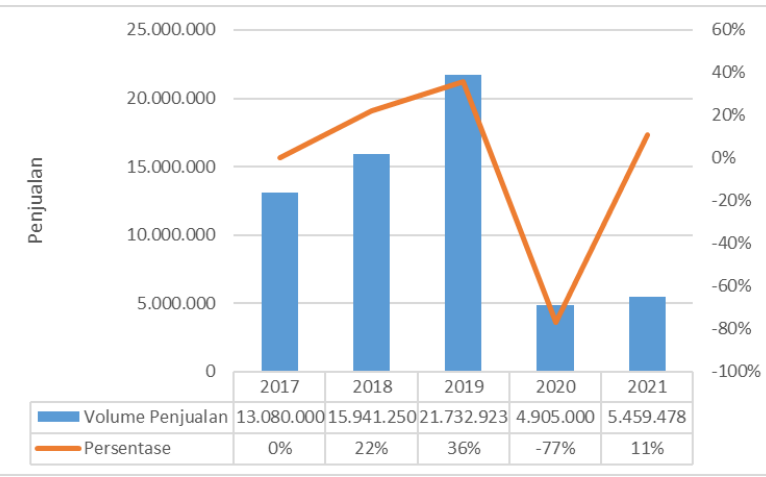

Grafik 6. Perkembangan Volume Penjualan Penjualan Batu Bata

Jika diteliti lebih lanjut maka akan terlihat persentase volume penjualan setiap tahunya mengalami peningkatan. Untuk keseluruhan dalam 5 tahun terakhir, Usaha Kilang Batu Bata mengalami perkembangan yang sangat pesat dilihat dari volume penjualan. Hal ini jelas dipengaruhi oleh tingginya permintaan batu bata khususnya di daerah Ulee Kareng dan sekitarnya. Selain itu Usaha Kilang Batu Bata juga menawarkan harga yang sangat murah.

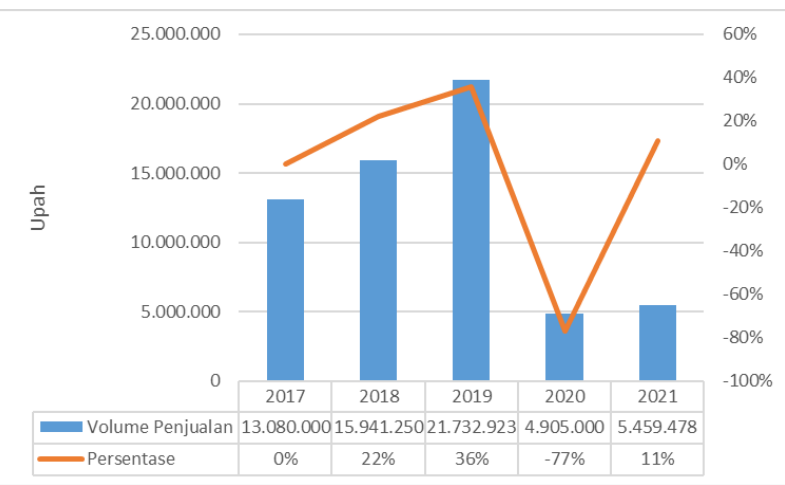

Grafik 7. Perkembangan tingkat upah tenaga kerja per unit 
Jika diteliti lebih lanjut maka akan terlihat persentase tingkat upah tenaga kerja setiap tahunya mengalami peningkatan. Untuk keseluruhan dalam 5 tahun terakhir, Usaha Kilang Batu Bata mengalami perkembangan dilihat dari tigkat upah tenaga kerja. Hal ini jelas dipengaruhi oleh tingginya permintaan batu bata khususnya di daerah ulee kareng dan sekitarnya. selain itu Usaha Kilang Batu Bata juga menawarkan harga yang sangat murah.

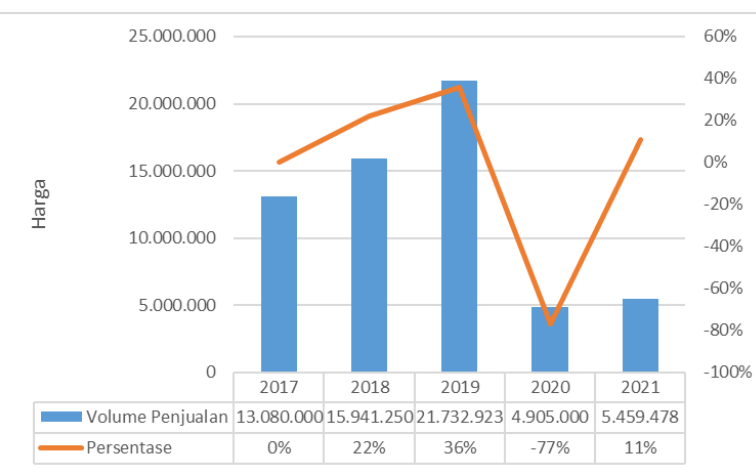

Grafik 8. Perkembangan Harga Jual Per Unit

Jika diteliti lebih lanjut maka akan terlihat persentase harga jual per unit batu bata setiap tahunya mengalami peningkatan dalam 5 tahun terakhir, usaha kilang batu bata mengalami perkembangan yang sangat pesat dilihat dariproduksi. Hal ini jelas dipengaruhi oleh tingginya permintaan batu bata khususnya di daerah ulee kareng dan sekitarnya. selain itu Usaha Kilang Batu Bata juga menawarkan harga yang sangat murah. Untuk lebih jelas dan memudahkan dalam mengetahui perkembangan keuntungan Usaha kilang batu bata dari tabel di atas maka dibuatlah perkembangankeuntungan. Berikut grafik perkembangan Keuntungan Usaha Kilang Batu Bata dari tahun 2017 sampai dengantahun 2021.

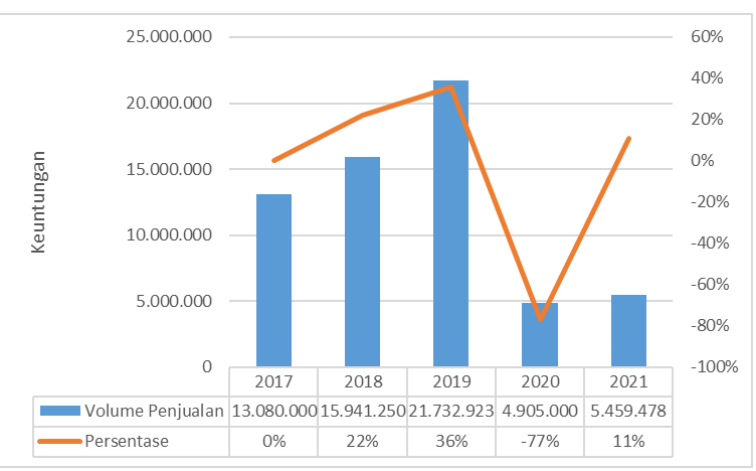

Grafik 9. Perkembangan Keuntungan Usaha
Jika diteliti lebih lanjut maka akan terlihat persentase keuntungan kilang batu bata setiap tahunya mengalami peningkatan. dalam 5 tahun terakhir, usaha kilang batu bata mengalami perkembangan yang sangat pesat dilihat dari keuntungan, Walaupun pada tahun 2020-2021 penurunan sangat tajam terjadi diakibatkan oleh pandemic covid-19, tetapi pada pertengangan 2021 kembali penignkatan terjadi dikarenakan adanya pembangunan rumah di daerah Kota Banda Aceh. Hal ini jelas dipengaruhi oleh tingginya permintaan batu bata khususnya di daerah ulee kareng dan sekitarnya. selain itu Usaha Kilang Batu Bata juga menawarkan harga yang sangat murah.

\section{Kelayakan Usaha Analisis kelayakan usaha dilakukan dengan menghitung (BCR)}

Analisis finansial dalam penelitian ini dilakukan untuk mengetahui layak atau tidak layaknya Usaha Kilang Batu Bata. Perhitungan yang dilakukan antara lain: Modal dan Penerimaan. Suatu usaha layak untuk dilaksanakan apabila mempunyai kriteria BCR $>1$ da berlaku, maka secara finansial usaha ini layak untuk dilaksanakan. Berdasarkan perhitungan kelayakan Usaha Kilang Batu Bata dilihat dari modal dan penerimaan diperoleh BCR Usaha Kilang Batu Bata yaitu untuk tahun 2017 Modal yang dikeluarkan sebesar Rp 2.354.400.000, dan penerimaan pada tahun tersebut sebesar $\mathrm{Rp}$ 5.886.000.000. maka usaha tersebut layak untuk dikembangkan. tahun 2018 Modal yang dikeluarkan sebesar $\mathrm{Rp}$ 3.264.768.000, dan penerimaan pada tahun tersebut sebesar Rp. 8.767.687.500. maka usaha tersebut layak untuk di kembangkan. tahun 2019 Modal yang dikeluarkan sebesar Rp. 4.237.920.000, dan penerimaan pada tahun tersebut sebesar Rp. 11.953.107.692. maka usaha tersebut layak untuk di kembangkan. tahun 2020 Modal yang dikeluarkan sebesar 3.531.600.000, dan penerimaan pada tahun tersebut sebesar Rp. 3.090.150.000. maka usaha tersebut tidak layak untuk di kembangkan. tahun 2021 modal yang dikeluarkan sebesar $\mathrm{Rp}$ 3.453.120.000, dan penerimaan pada tahun tersebut sebesar $\mathrm{Rp}$. 3.548.660.870. maka usaha tersebut tidak layak untuk di kembangkan.

\section{Aspek Pemasaran}

Berdasarkan hasil penelitan, dapat disimpulkan 
perkembangan Usaha Kilang Batu Bata dilihat dari aspek pasar: Usaha Kilang Batu Bata ditnjau dari aspek pasar mengalami perkembangan hal ini terlihat dalam volume penjualan batu bata yang dikeluarkan Usaha Kilang Batu Bata pada tahun 2017 sebanyak 13.080.000 biji. sedangkan pada tahun berikutnya 2018 volume penjualan batu bata sebanyak 15.941.250 biji. Pada periode tahun 2019 volume penjualan batu bata sebanyak 21.732 .923 biji. pada periode tahun 2020 volume penjualan batu bata sebayak 4.905 .000 biji. Pada periode tahun 2021 volume penjualan batu bata sebanyak 5.459 .478 biji. Dalam kurun waktu dari tahun 2017 sampai 2019 volume penjualan batu bata mengalami peningkatan hal ini didukung oleh harga jual yang murah, dapat membeli satuan atau eceran, kualitas produk (batu bata) baik, barang produksi dapat dibeli ditoko-toko bangunan. Sedangkan pada tahun 2020-2021 penjualan menjadi menurun karena tidak adanya permintaan pasar dan bahan baku menjadi tinggi.

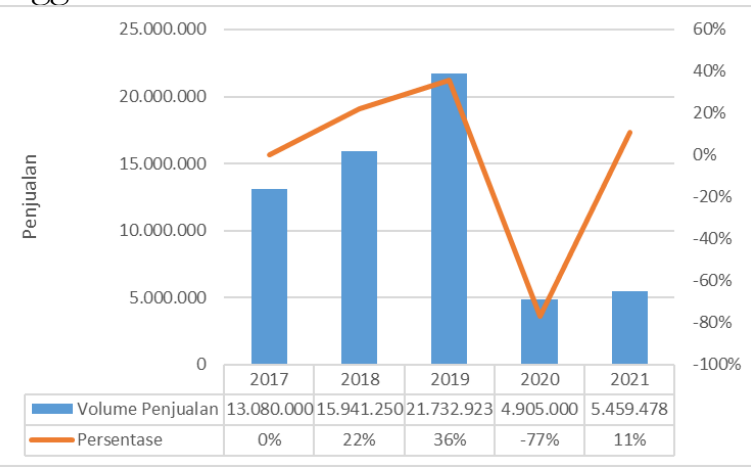

Grafik 10. Perkembangan Penjualan Batu Bata

\section{Kesimpulan}

Berdasarkan hasil penelitan dan pembahasan, dapat disimpulkan bahwa perkembangan Usaha kilang Batu Bata dilihat:

1) Berdasarkan Hasil analisis data mengenai Jumlah Produksi, Tenaga Kerja, Modal Kerja, Volume Penjualan, Tingkat Upah, Harga Jual, Biaya Bahan Baku dan Keuntungan Usaha Kilang Batu Bata mengalami peningkatan setiap tahun. Berbeda pada tahun 2020-2021 terjadi penurunan yang diakibatkan oleh menurunya permintaan dan tingginya bahan baku pengolahan batu bata.
2) Hasil perhitungan kelayakan usaha ditinjau dari segi Modal dan Penerimaan dengan menggunakan rumus BCR yang menunjukkan bahwa variabel modal dan penerimaan berpengaruh positif terhadap kelayakan Usaha Kilang Batu Bata 2017 s/d tahun 2019 ataupun dalam arti kata lain bahwa Usaha Kilang Batu Bata tidak rugi. Terbalik pada tahun 2020-2021 dimana usaha batu bata menurunya permintaan tetapi stok menjadi banyak dan tidak ditemukan kerugian yang berdampak. Akan tetapi, pendapatan usaha batu bata menjadi menurun.

3) Usaha kilang batu bata dilihat dari aspek pemasaran mengalami perkembangan yang positif pada tahun 2017-2019.hal ini dapat dilihat dari jumblah permintaan yang selalu meningkat setiap tahunnya. Berbeda pada tahun 2020-2021 dimana perkembangan dari aspek pemasaran menjadi rendah, dikarena adanya pandemic dan berkurangnya pembangunan di Kota Banda Aceh.

\section{Ucapan Terima Kasih}

Ucapan terima kasih peneliti kepada Deputi Bidang Penguatan Riset dan Pengembangan, Kementerian Pendidikan, Kebudayaan, Riset, dan Teknologi yang telah mendanai kegiatan penelitian pada skema Penelitian Dosen Pemula (PDP) Tahun anggaran 2021. Selanjutnya kepada LLDIKTI Wilayah XIII Provinsi Aceh yang telah menfasilitasi kegiatan penelitian ini dan tak lupa pula kepada LP3M Universitas Serambi Mekkah (USM) yang telah berkontribusi dalam penanganan administrasi dan perizinan sehingga penelitian ini sesuai dengan jadwal dan rencana tim peneliti.

\section{Daftar Pustaka}

Agustin, H. (2017). Studi Kelayakan Bisnis Syariah.

As, F. K., Novareza, O., \& Santoso, P. B. (2017). Peningkatan Kualitas Produk Batu Bata Merah Dengan Memanfaatkan Limbah Abu Serat Sabut Kelapa Dan Abu Serbuk Gergaji. 
Asang, H. S. (2019). Membangun Sumberdaya Manusia Berkualitas: Prespektif Organisasi Publik. Firstbox Media.

Budiarto, R., Putero, S. H., Suyatna, H., Astuti, P., Saptoadi, H., Ridwan, M. M., \& Susilo, B. (2018). Pengembangan UMKM Antara Konseptual dan Pengalaman Praktis. UGM PRESS.

Darsih, D., Iyan, R. Y., \& Pailis, E. A. (2017). Peranan Sektor Industri Kecil Batu Bata Press dalam Meningkatkan Pendapatan Masyarakat di Kecamatan Tenayan Raya Kota Pekanbaru (Doctoral dissertation, Riau University).

Djatmiko, A., \& Pudyastiwi, E. (2020). Hambatan dan Tantangan Usaha Mikro, Kecil dan Menengah (UMKM) Indonesia dalam Menghadapi Pandemi Covid-19. Jurnal Pendidikan Kewarganegaraan Undiksha, 8(3), 117123.

Fathonah, N. (2018). Gaya kepemimpinan kh. Mughni labib dan implementasinya di yayasan pendidikan al-ittihaad darussa'adah pasir kidul kecamatan purwokerto barat kabupaten banyumas (Doctoral dissertation, IAIN Purwokerto).

Hardiyanto, R. (2019). Analisis Penyerapan Tenaga Kerja pada Industri Kecil dan Menengah Batik di Kecamatan Laweyan Kota Surakarta (Doctoral dissertation, Universitas Muhammadiyah Surakarta).

Inayah, M. N. (2018). Pola Persebaran Dan Distribusi Produk Industri Batu Bata Di Kecamatan Patikraja Kabupaten Banyumas (Doctoral Dissertation, Universitas Muhammadiyah Purwokerto).
Indriasari, A., Suryanti, N., \& Afriana, A. (2017). Pembiayaan Usaha Mikro, Kecil, Dan Menengah Melalui Situs Crowdfunding "Patungan. Net" Dikaitkan Dengan Undang-Undang Nomor 20 Tahun 2008 Tentang Usaha Mikro, Kecil, Dan Menengah. ACTA DIURNAL Jurnal Ilmu Hukum Kenotariatan, 1(1), 87-102.

Indriasari, A., Suryanti, N., \& Afriana, A. (2017). Pembiayaan Usaha Mikro, Kecil, Dan Menengah Melalui Situs Crowdfunding "Patungan. Net" Dikaitkan Dengan Undang-Undang Nomor 20 Tahun 2008 Tentang Usaha Mikro, Kecil, Dan Menengah. ACTA DIURNAL Jurnal Ilmu Hukum Kenotariatan, 1(1), 87-102.

Kamila, E. F. (2020). Peran Industri Halal Dalam Mengdongkrak Pertumbuhan Ekonomi Indonesia Di Era New Normal. LIKUID: Jurnal Ekonomi Industri Halal, 1(1).

Kristiyanti, M. (2012). Peran strategis usaha kecil menengah (UKM) dalam pembangunan nasional. Majalah Ilmiah Informatika, 3(1), 63-89.

laura Hardilawati, W. (2020). Strategi Bertahan UMKM di Tengah Pandemi Covid-19. Jurnal Akuntansi dan Ekonomika, 10(1), 89-98.

Narto, N., \& HM, G. B. (2020). Penguatan Strategi Pemasaran Pudak di Tengah Pandemi Covid-19 untuk Meningkatkan Keunggulan Bersaing Usaha Mikro Kecil Menengah Kota Gresik. Jurnal INTECH Teknik Industri Universitas Serang Raya, 6(1), 48-54.

Pakpahan, A. K. (2020). Covid-19 Dan Implikasi Bagi Usaha Mikro, Kecil, Dan Menengah. Jurnal Ilmiah Hubungan Internasional, 59-64. 
Ramadan, W. C., \& Rosyidi, S. (2017). Perbandingan Norma Produksi Islam Dengan Produksi Pada Industri Bordir di Kecamatan Bangil (Studi Kasus Pada Perusahaan Faiza Bordir). Jurnal Ekonomi Syariah Teori dan Terapan, 4(9), 684.

Solikin, A., Fatchurahman, M., \& Supardi, S. (2017). Pemimpin Yang Melayani Dalam Membangun Bangsa Yang Mandiri. Anterior Jurnal, 16(2), 90-103.

Suci, Y. R. (2017). Perkembangan UMKM (Usaha mikro kecil dan menengah) di Indonesia. Cano Ekonomos, 6(1), 51-58.

Thaha, A. F. (2020). Dampak covid-19 terhadap UMKM di Indonesia. BRAND Jurnal Ilmiah Manajemen Pemasaran, 2(1), 147-153.

Utama, D. D. T., \& DARWANTO, D. (2013). Pengembangan Usaha Mikro Kecil dan Menengah (UMKM) Berbasis Ekonomi Kreatif di Kota Semarang (Doctoral dissertation, Fakultas Ekonomika dan Bisnis).
Vicky, M. (2019). Evaluasi sistem informasi akuntansi proses produksi dan persediaan barang jadi pada pt. Astra nippon gasket indonesia (studi kasus pada PT. Astra Nippon Gasket Indonesia) (Doctoral dissertation, Universitas Darma Persada).

Wijayanti, R., \& Mulyati, S. (2018). Rancangan Bangun Sistem Informasi Berbasis Web Untuk Memantau Produksi dan Kegiatan Antar Divisi di Agro Pantes Tbk. International Journal of Education, Science, Technology, and Engineering, 1(1), 1-15.

Yuniarti, D. (2018). Analisis Bauran Pemasaran Terhadap Keputusan Pembelian Produk Minuman (Survei pada konsumen Teh pucuk harum di CV Langgeng Jaya Sentosa Kabupaten Bojonegoro) (Doctoral dissertation, Universitas Bojonegoro). 